\title{
Dimethyl carbonate synthesis via transesterification of propylene carbonate with methanol by ceria-zinc catalysts: Role of catalyst support and reaction parameters
}

\author{
Praveen Kumar, Vimal Chandra Srivastava ${ }^{\dagger}$, and Indra Mani Mishra
}

Department of Chemical Engineering, Indian Institute of Technology Roorkee, Roorkee 247667, Uttarakhand, India (Received 26 December 2014 - accepted 16 February 2015)

\begin{abstract}
Ceria and zinc oxide catalyst were impregnated onto various oxide supports, namely $\mathrm{Al}_{2} \mathrm{O}_{3}, \mathrm{TiO}_{2}$ and $\mathrm{SiO}_{2}$, individually by deposition-coprecipitation method. The synthesized catalysts (CZA, CZS and CZT having supports $\mathrm{Al}_{2} \mathrm{O}_{3}, \mathrm{TiO}_{2}$ and $\mathrm{SiO}_{2}$, respectively) were characterized by X-ray diffraction (XRD), $\mathrm{NH}_{3}$ - and $\mathrm{CO}_{2}$-temperature programmed desorption (TPD) and $\mathrm{N}_{2}$ adsorption. These catalysts were used for synthesis of dimethyl carbonate (DMC) from methanol and propylene carbonate in a batch reactor. CZS was found to have larger average grain size as compared to CZA and CZT. Composite oxides (catalysts) were found to contain individual phases of $\mathrm{ZnO}, \mathrm{CeO}_{2}$ and some spinel forms of $\mathrm{Zn}$, Ce along with their supports. CZS having highest basicity and surface area showed better catalytic activity as compared to CZA and CZT. Effect of reaction temperature and methanol/PC molar ratio on DMC yield was studied and a reaction mechanism has been discussed. Maximum DMC yield of $77 \%$ was observed with CZS catalyst at $170{ }^{\circ} \mathrm{C}$ with methanol/PC molar ratio of 10 .
\end{abstract}

Keywords: DMC, Transesterification Catalysts, Propylene Carbonate, Methanol

\section{INTRODUCTION}

Dimethyl carbonate (DMC) is an environmentally benign building block chemical compound that has diversified uses in the chemical industry [1]. It has low eco-toxicity, and low persistence and bioaccumulation in life forms [2,3]. DMC is a non-toxic chemical widely used as a methylation agent for substituting the highly toxic dimethyl sulfate and dimethyl halides, and also as a carbonylation agent in various applications [1-3]. The high dielectric constant of DMC allows it to be used as an electrolyte too. It is also used in electrolytic lithium batteries [3]. DMC is used in the production of glycerol carbonate [4,5], O-methylation [6], diphenyl carbonate [7], and can be used as a substitute in place of many conventional solvents [4-8].

$\mathrm{DMC}$ is also an alternative oxygenate additive in gasoline-based fuels in place of toxic and poorly biodegradable methyl tert-butyl ether (MTBE). It has higher oxygen content on weight basis (53.3\%) in comparison to methanol (50\%), ethanol (34.89\%) and MTBE (17.6\%). The use of DMC in gasoline also reduces the emission of solid particulates (SPM) and NOx [1-3].

Traditionally, DMC was produced by using the phosgenation process, methanol oxycarbonylation process and methyl nitrite carbonylation process. Phosgenation of methanol was considered to be hazardous, and therefore, this process of DMC production was abandoned by 1980 . Currently, DMC is predominantly produced from methanol oxycarbonylation process [1-3]. These conventional DMC production processes are not considered to be safe, as they suffer from problems such as the production of carbon monox-

${ }^{\dagger}$ To whom correspondence should be addressed.

E-mail: vimalcsr@yahoo.co.in, vimalfch@iitr.ac.in

Copyright by The Korean Institute of Chemical Engineers. ide, hydrogen chloride and nitric oxide through the complex reaction pathways [1-3]. Some other pathways used for the production of DMC such as the direct synthesis from $\mathrm{CO}_{2}$ suffer from low conversion to DMC, and has thermodynamic limitations [9-12]. Urea methanolysis process suffers from low selectivity because of the formation of the byproducts such as methyl carbamate, N-methyl urea, N-methyl methyl carbamate [13-15]. Transesterification of propylene carbonate (PC) with methanol is a promising method for the synthesis of DMC. The catalytic mechanism for transesterification
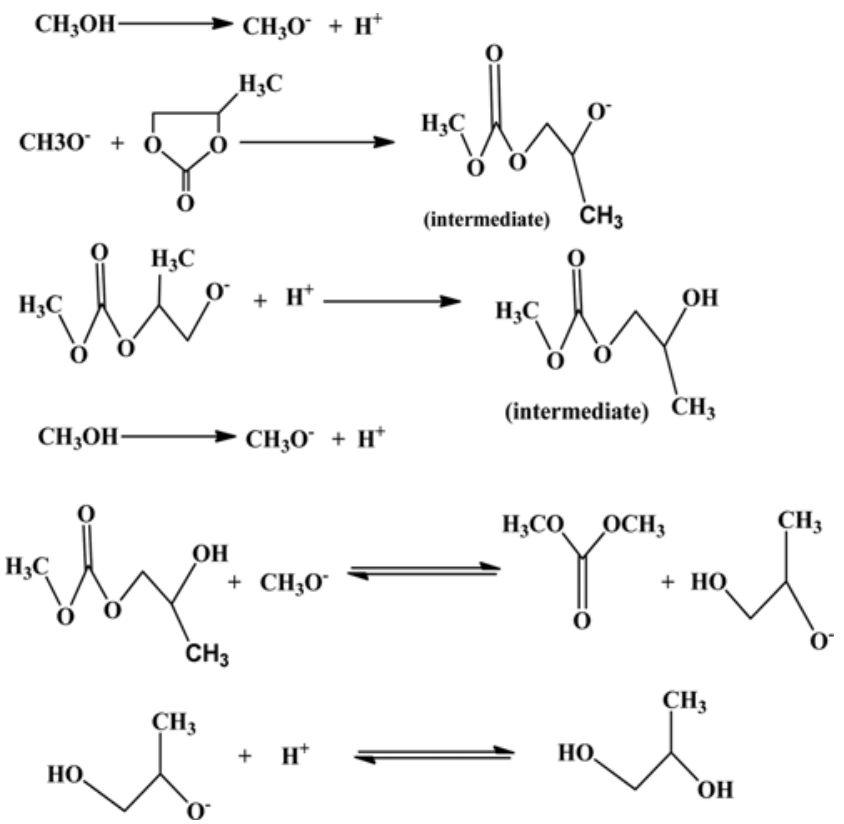

Scheme 1. Proposed reaction mechanism of DMC synthesis. 
of PC with methanol is shown in Scheme 1. PC gets easily converted to $\mathrm{DMC}$ in the presence of a catalyst, but the reaction is reversible and propylene glycol (PG) is formed as byproduct [15]. In this reaction, yield of DMC is higher than other routes. Also, the number of byproducts is less; therefore, separation of products and raw materials is easy and economical as compared to other routes of DMC formation. Although each production method has its own drawback, transesterification of PC with methanol is a promising and feasible method for the synthesis of DMC, especially in the framework of green chemistry, and is environmentally benign as compared to other routes. This route is sustainable, clean, and there is no formation of any harmful or waste byproduct [15].

Ceria-zinc oxide based catalysts have been used in CO oxidation, steam reforming, methanolysis, desulfurization, etc. as shown in Table S1. Comparative assessment of the characterization of ceriazinc based catalysts and their applications are given in Table S1. It can be seen that the ceria-zinc oxide supported on $\mathrm{Al}_{2} \mathrm{O}_{3} / \mathrm{SiO}_{2} / \mathrm{TiO}_{2}$ has never been used for the synthesis of DMC using transesterification reaction. Most of the researchers also did not characterize the ceria-zinc catalyst.

Various catalysts have been investigated for the synthesis of DMC from PC and methanol such as ion exchange resins [16], pure metal oxide [17], basic ionic liquids [18], mixed metal oxide [19] and double metal cyanide [20]. Comparative performance of various catalysts used for the synthesis of DMC using transesterification of PC is given in Table 1 [20-24]. Srivastava et al. [20] reported that the double metal cyanide catalysts used for the synthesis of DMC gave $87.7 \%$ yield after $8 \mathrm{~h}$ reaction time. Jeong et al. [21] reported $54.1 \%$ conversion and $86.5 \%$ selectivity after $6 \mathrm{~h}$ with methanol to $\mathrm{PC}$ ratio $8: 1$. Wang et al. [22] reported 55\% conversion of $\mathrm{PC}$ using the $\mathrm{CaO}-$ $\mathrm{ZrO}_{2}$ catalyst after $2 \mathrm{~h}$ of reaction with a methanol to PC ratio of $6: 1$. Liu et al. [23] using $\mathrm{Na}-\mathrm{ZrO}_{2}$ catalysts, reported $50 \%$ conversion of PC after $1.5 \mathrm{~h}$ with a methanol to PC ratio of $5: 1$. Unikrishnan and Srinivas [24] reported 65.4\% PC conversion using hydrotalcite based catalyst for the synthesis of DMC from methanol and PC (with 10:1 ratio) in $2 \mathrm{~h}$ time. To the best of our knowledge, transesterification of $\mathrm{PC}$ with methanol in the presence of ceriazinc oxide catalyst supported on $\mathrm{Al}_{2} \mathrm{O}_{3} / \mathrm{SiO}_{2} / \mathrm{TiO}_{2}$ has not been reported to date.

In this work, a series of cerium-zinc composite oxide catalysts were synthesized using the deposition-coprecipitation method and characterized using X-ray diffraction (XRD), $\mathrm{N}_{2}$-sorption and Fou- rier transform infrared spectroscopy (FTIR) techniques. Basicity and acidity of the synthesized catalysts were determined by $\mathrm{CO}_{2}-$ and $\mathrm{NH}_{3}$-temperature-programmed desorption (TPD), morphology of catalysts was studied using scanning electron microscopy (SEM), transmission electron microscopy (TEM) and atomic force microscopy (AFM). The catalysts were then tested for the production of DMC using transesterification of PC with methanol.

\section{EXPERIMENTS}

\section{Materials}

Zinc nitrate hexahydrate $\left(\mathrm{Zn}\left(\mathrm{NO}_{3}\right)_{2} \cdot 6 \mathrm{H}_{2} \mathrm{O}\right)$, cerium nitrate hexahydrate $\left(\mathrm{Ce}\left(\mathrm{NO}_{3}\right)_{3} \cdot 6 \mathrm{H}_{2} \mathrm{O}\right)$ and DMC were purchased from Himedia Chemicals, India; $\mathrm{Al}_{2} \mathrm{O}_{3}$ and $\mathrm{TiO}_{2}$ were kindly supplied by Evonik Degussa Gmbh; $\mathrm{SiO}_{2}$ from Thomas Baker; ammonia solution and methanol from Renkem, India. Standard samples of DMC, PC and PG were purchased from Aldrich, India. Only analytical grade (AR) chemicals were purchased and used as required. Double distilled water was used in the synthesis of the catalyst, washing, etc.

\section{Catalyst Preparation}

Ceria and zinc oxide were impregnated onto various oxide supports, namely $\mathrm{Al}_{2} \mathrm{O}_{3}, \mathrm{TiO}_{2}$ and $\mathrm{SiO}_{2}$. These catalysts were synthesized in the $\mathrm{CeO}_{2}: \mathrm{ZnO}$ : support=1:1:2 molar ratio by a deposition-coprecipitation method using liquid ammonia as the precipitating agent. Metal precursors such as hexahydrates of cerium nitrate and zinc nitrate were dissolved separately in double distilled water with a 1:1 molar ratio and mixed together at room temperature. The supporting oxide was dispersed in water, stirred vigorously and thereafter metal precursor cerium-zinc solutions were mixed together [25]. The prepared mixture was diluted with $100 \mathrm{~mL}$ of double distilled water and stirred for $1 \mathrm{~h}$. Liquid ammonia was added drop by drop in the mixture under vigorous stirring until the $\mathrm{pH}$ reached 8.5. The obtained precipitate was filtered and washed with double distilled water until it was free from all anion impurities. Thereafter, the solid precipitate was dried at $110^{\circ} \mathrm{C}$ for $24 \mathrm{~h}$ and calcined at $500{ }^{\circ} \mathrm{C}$ under air atmosphere for $4 \mathrm{~h}$. The composite oxides, thus formed, were denoted as CZA, CZT and CZS, where C, Z, A, T and $\mathrm{S}$ denote $\mathrm{Ce}, \mathrm{Zn}, \mathrm{Al}$, Ti, and $\mathrm{Si}$, respectively.

\section{Catalyst Characterization}

The metal content was quantified by energy disperse X-ray (EDX) analysis using field emission scanning electron microscope (FESEM) (quanta 200 FEG, FEI Netherlands) and a special attachment

Table 1. Comparative study of catalysts with different reaction conditions

\begin{tabular}{|c|c|c|c|c|c|c|c|c|}
\hline Catalyst & $\begin{array}{l}\text { Methanol: } \\
\text { PC ratio }\end{array}$ & $\begin{array}{c}\text { Amount of } \\
\text { catalyst (wt } \%)\end{array}$ & $\begin{array}{l}\text { Reaction } \\
\text { time }(\mathrm{h})\end{array}$ & $\begin{array}{l}\text { Reaction temp. } \\
\qquad\left({ }^{\circ} \mathrm{C}\right)\end{array}$ & $\begin{array}{c}\text { PC conversion } \\
(\%)\end{array}$ & $\begin{array}{c}\text { Selectivity } \\
(\%)\end{array}$ & $\begin{array}{c}\text { Yield } \\
(\%)\end{array}$ & Reference \\
\hline Fe-Zn cyanide & $10: 1$ & 5.75 & 8 & 170 & - & - & 87.7 & {$[20]$} \\
\hline $\mathrm{CaO}-\mathrm{ZrO}_{2}$ & $6: 1$ & 1.5 & 2 & 150 & 55 & - & - & {$[22]$} \\
\hline $\mathrm{Na}-\mathrm{ZrO}_{2}$ & $10: 1$ & 1.5 & 1.5 & 160 & 50 & - & - & [23] \\
\hline Mg-Al-La & $10: 1$ & 5.0 & 2 & 150 & 65.4 & 87.7 & & {$[24]$} \\
\hline $\mathrm{CZA}$ & $10: 1$ & 1.0 & 6 & 170 & - & - & 68 & This work \\
\hline CZS & $10: 1$ & 1.0 & 6 & 170 & - & - & 77 & This work \\
\hline $\mathrm{CZT}$ & $10: 1$ & 1.0 & 6 & 170 & - & - & 23 & This work \\
\hline
\end{tabular}

PC: Propylene carbonate 
of electron backscatter diffraction (EDBS) equipped with an analysis software. The estimates of the metal content by this method may have an error of $\pm 5 \%$. TEM images were obtained by using TECNAI G 20 S-TWIN, FEI, Netherlands at $200 \mathrm{kV}$. For TEM analysis, the catalysts were dispersed in ethanol solution, which was sonicated for $60 \mathrm{~min}$. Afterwards, a drop of the dispersion was placed on a TEM copper grid.

Morphology of the catalysts was also studied using AFM supplied by M/s Molecular Tools and Devices for Nanotechnology (NT-MDT) which was equipped with NOVA software for image analysis. The samples were prepared in ethanol; a small amount of sample dispersed in ethanol solution, which was sonicated for 120 min. Afterwards, a small amount of solution dispersion was placed on a glass plate and dried at room temperature for $12 \mathrm{~h}$. Then this glass plate was used for AFM analysis.

Thermo-gravimetric analysis (TGA) of the synthesized catalysts was carried out using SII 6300 EXSTAR analyzer. The weight loss was estimated from room temperature to $1,000^{\circ} \mathrm{C}$ with heating rate of $10 \mathrm{~K} / \mathrm{min}$ under flushing nitrogen atmosphere.

FTIR spectroscopy was used to find the surface functional groups of the synthesized catalysts by using an FTIR spectrophotometer (Thermo Nicolet, Model Magna 760) in the wave number range of $400-4,000 \mathrm{~cm}^{-1}$ using a hand pressed $\mathrm{KBr}$ pellet as the reference material.

Various analytical methods were used for characterizing the morphology, phase structure, and physical properties of the prepared catalysts. XRD patterns of the catalyst surface were obtained from an X-ray diffractometer (Brueker AXS, Diffractomer D8, Germany) with $\mathrm{Cu}-\mathrm{K}_{\alpha}$ radiation $(\lambda=1.5406 \AA)$ and $\mathrm{X}$-ray gun operated at 40 $\mathrm{kV}$ and $30 \mathrm{~mA}$. The scanning of the catalysts was done in the $2 \theta$ range of $5^{\circ} \leq 2 \theta \leq 100^{\circ}$. XRD line positions were found with a step size of $0.02^{\circ}$. The crystallinity of the sample was identified by using ICDD-JCPDS data base. Crystal size (L) was calculated from the Scherrer equation.

$$
\mathrm{L}=\frac{\mathrm{K} \cdot \lambda}{\beta \cos \theta}
$$

where, $\mathrm{K}$ is the Scherrer's constant (generally taken as 0.9 ), $\lambda$ is the wavelength of X-ray radiation and is equal to $1.5405 \AA$, $\beta$ is the full width of the reflection at half maximum (FWHM) in radians and $\theta$ is the scattering angle of the main reflection.

The textural properties of the catalysts were determined by using multi-point $\mathrm{N}_{2}$ adsorption-desorption at $-195^{\circ} \mathrm{C}$ using a Micromeritics ASAP 2020 instrument. The sample was kept overnight at $110^{\circ} \mathrm{C}$ and then degassed for $12 \mathrm{~h}$ at $200^{\circ} \mathrm{C}$ under high vacuum. Data of $\mathrm{N}_{2}$ adsorbed at different relative pressures were analyzed by BrunauerEmmett-Teller (BET) [26] and Barrett-Joyner-Halenda (BJH) [27] isotherm equations to determine various textural properties.

$\mathrm{NH}_{3}$ - and $\mathrm{CO}_{2}$-TPD was performed using Micromeritics ChemiSorb 2720 instrument fitted with a thermal conductivity detector (TCD). The $50 \mathrm{mg}$ sample was first degassed under helium flow $(25 \mathrm{~mL} / \mathrm{min})$ in a quartz $\mathrm{U}$-tube at $200^{\circ} \mathrm{C}$ for $4 \mathrm{~h}$, and then allowed to cool to room temperature under flowing helium. The $\mathrm{NH}_{3}$ adsorption was performed by admitting $10 \% \mathrm{NH}_{3} / \mathrm{He}$ stream flow $(25 \mathrm{~mL} / \mathrm{min})$ at $50{ }^{\circ} \mathrm{C}$ up to saturation. Subsequently, the sample was exposed to a flow of helium $(25 \mathrm{~mL} / \mathrm{min})$ at $50^{\circ} \mathrm{C}$ for $2 \mathrm{~h}$ to remove any physically bound ammonia from the surface. Desorption study was carried out in the temperature range of $50-900{ }^{\circ} \mathrm{C}$ at a heating rate of $10 \mathrm{~K} / \mathrm{min}$ under helium flow $(20 \mathrm{~mL} / \mathrm{min}) . \mathrm{CO}_{2^{-}}$ TPD followed the $\mathrm{NH}_{3}$-TPD procedure. The acidity and basicity of the synthesized catalysts were calculated from $\mathrm{NH}_{3}$-TPD and $\mathrm{CO}_{2}$-TPD peak areas using calibration curves. Joe et al. [13] activated the $\mathrm{CeO}_{2}-\mathrm{ZnO}$ catalysts at $500{ }^{\circ} \mathrm{C}$ and studied the TPD profile in the temperature range of $0-900{ }^{\circ} \mathrm{C}$. Similarly, He et al. [28] used calcination temperature of $750{ }^{\circ} \mathrm{C}$ for $\mathrm{CeO}_{2} / \mathrm{ZnO}$ nanostructured microsphere activation and studied the $\mathrm{CO}_{2}$-TPD profile in the temperature range between $0-800^{\circ} \mathrm{C}$. On the basis of these studies, in the present study, TPD in the present study was analyzed in the temperature range of $0-1,000{ }^{\circ} \mathrm{C}$.

\section{Reaction Procedure}

Synthesized catalysts were tested for their activity to produce DMC through transesterification of PC with methanol. Experiments were performed in a $300 \mathrm{~mL}$ steel autoclave (Parr, model 4843). $0.25 \mathrm{~mol}$ of PC along with $2.5 \mathrm{~mol}$ of methanol and a known mass of the synthesized catalyst (about $1.0 \mathrm{wt} \%$ of the PC) were placed in the steel autoclave. The autoclave was flushed with nitrogen under continuous heating and stirring at $550 \pm 50 \mathrm{rpm}$ so as to increase the autoclave pressure to 2-5 bar. The reactions were carried out at $170{ }^{\circ} \mathrm{C}$ and autogenic pressure up to $25 \mathrm{bar}$ for $4 \mathrm{~h}$. After the desired time, the reaction was stopped and the product mixture was cooled to $10{ }^{\circ} \mathrm{C}$ with the help of cold water and ice for $30 \mathrm{~min}$. After that the catalyst was separated by centrifugation/filtration. The reaction products were analyzed by gas chromatograph (Thermo Electron Corporation, model Trace GC ultra) equipped with flame ionization detector (FID) with HP-5 capillary column. The initial column temperature was $40^{\circ} \mathrm{C}$ with a hold time of $5 \mathrm{~min}$, after which it was increased at a rate of $3 \mathrm{~K} / \mathrm{min}$ to $90{ }^{\circ} \mathrm{C}$ with a hold time of $2 \mathrm{~min}$. Temperature was further increased at a rate of $10 \mathrm{~K} / \mathrm{min}$ to final temperature of $270^{\circ} \mathrm{C}$ where the hold time was $2 \mathrm{~min}$. Injector and detector temperatures were 250 and $270{ }^{\circ} \mathrm{C}$, respectively, with nitrogen gas used as the carrier gas.

\section{RESULTS AND DISCUSSION}

\section{Catalyst Characterization}

1-1. Morphological, Functional and Structural Properties

SEM and TEM images of the synthesized CZA, CZS and CZT catalysts are shown in Fig. 1. All the catalysts show spherical morphology, heterogeneous and crystalline structure. The EDX image mapping of CZA, CZS and CZT catalysts is shown in Fig. S1. The image maps show the distribution of $\mathrm{Al}, \mathrm{Si}$ and Ti metals in $\mathrm{CZA}$, $\mathrm{CZS}$ and CZT catalysts. In the CZA, the element $\mathrm{Al}$ is most scattered in CZA. Ti is well distributed and has least aggregation in CZT. EDX mapping also shows an almost even distribution of $\mathrm{Ce}$ and $\mathrm{Zn}$ in all catalysts. Average particle size of the catalysts as determined from the FE-SEM studies is found to be in the range of 5$20 \mathrm{~nm}$. TEM image show that all particles are in the diameter range of $\approx 5-10 \mathrm{~nm}$. AFM 3D images along with grain size distribution of the CZA, CZS and CZT is given in Fig. 2. Average grain size (as estimated using AFM image) of CZA, CZS and CZT was found to $5.25 \mathrm{~nm}, 8.65 \mathrm{~nm}$ and $4.10 \mathrm{~nm}$, respectively. Thus, CZS was found to have larger average grain size as compared to CZA and CZT. 

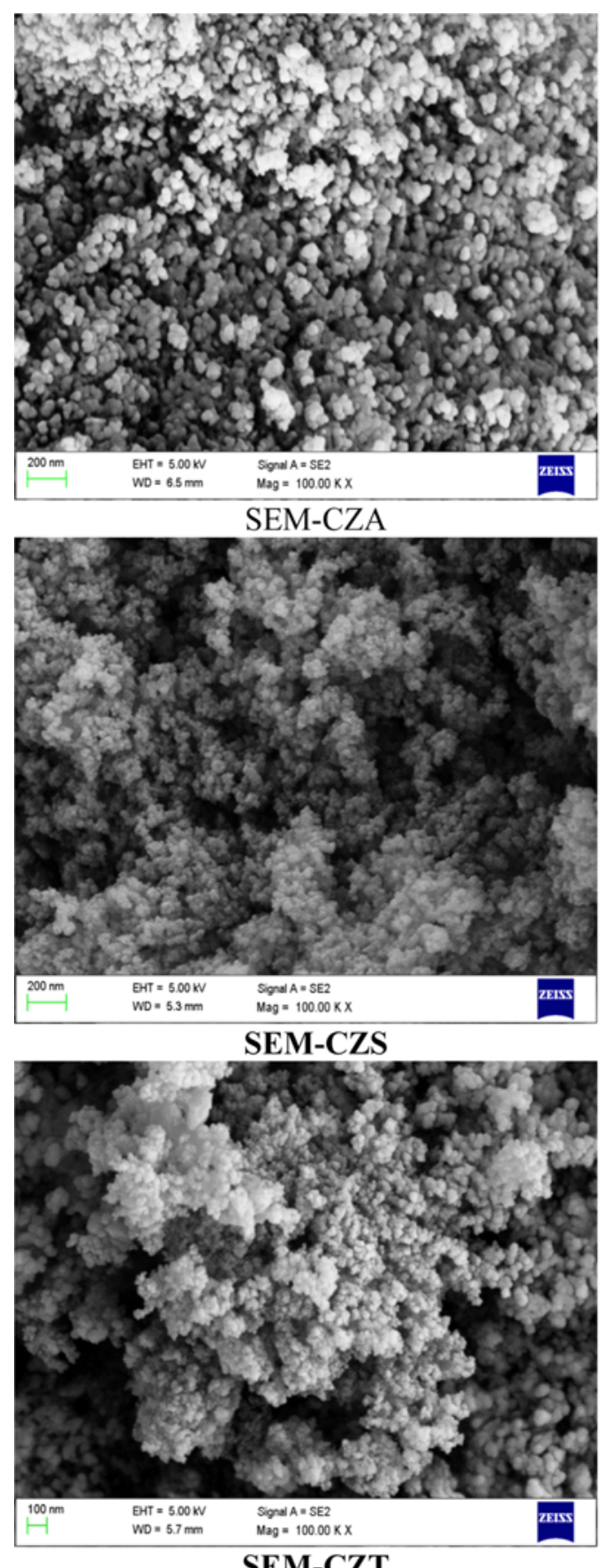

SEM-CZT

Fig. 1. SEM and TEM of CAZ, CZS and CZT catalyst.

FTIR spectra of CZA, CZS and CZT catalysts are shown in Fig. 3. The origin of the vibration band seen at $\sim 3,430 \mathrm{~cm}^{-1}$ can be ascribed to surface $\mathrm{O}-\mathrm{H}$ stretching, absorbed water and $\mathrm{N}-\mathrm{H}$ stretching amines groups. The peak at $\sim 2,925 \mathrm{~cm}^{-1}$ in all the catalysts is due to C-H stretching and the peak at $\sim 1,630 \mathrm{~cm}^{-1}$ is due to N-H bending. In CZA catalyst, the vibrations appearing in the peak at $735 \mathrm{~cm}^{-1}$ are due to $\mathrm{Al}-\mathrm{O}$ vibrations and that at $543 \mathrm{~cm}^{-1}$ is due to $\mathrm{Zn}-\mathrm{O}$ vibrations $[29,30]$. The characteristic vibration band for $\mathrm{Si}-\mathrm{O}-\mathrm{Si}$ of the $\left[\mathrm{SiO}_{4}\right]$ tetrahedron vibration unit in CZS is observed at $\sim 1,100 \mathrm{~cm}^{-1}$. The peaks at 463 and $805 \mathrm{~cm}^{-1}$ correspond to the $\mathrm{ZnO}$ and $\mathrm{O}-\mathrm{Si}-\mathrm{O}$

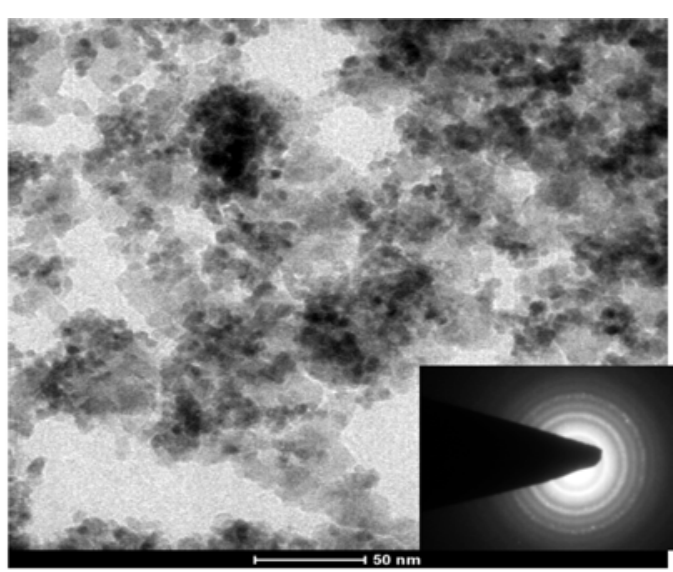

TEM-CZA

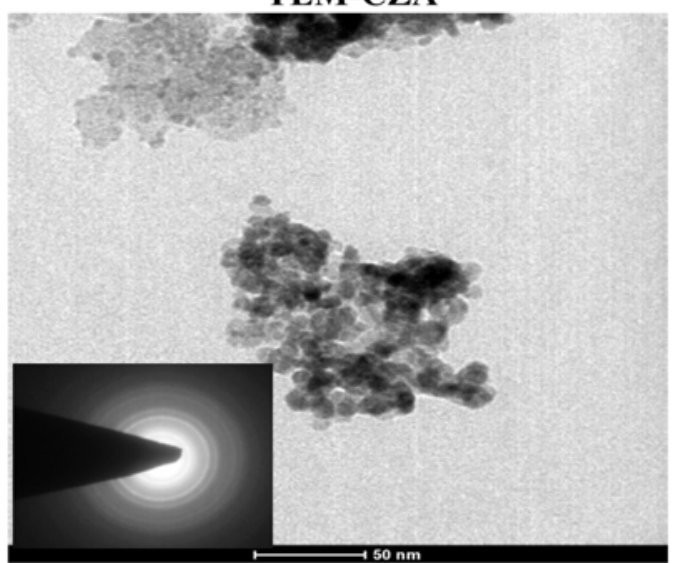

TEM-CZS

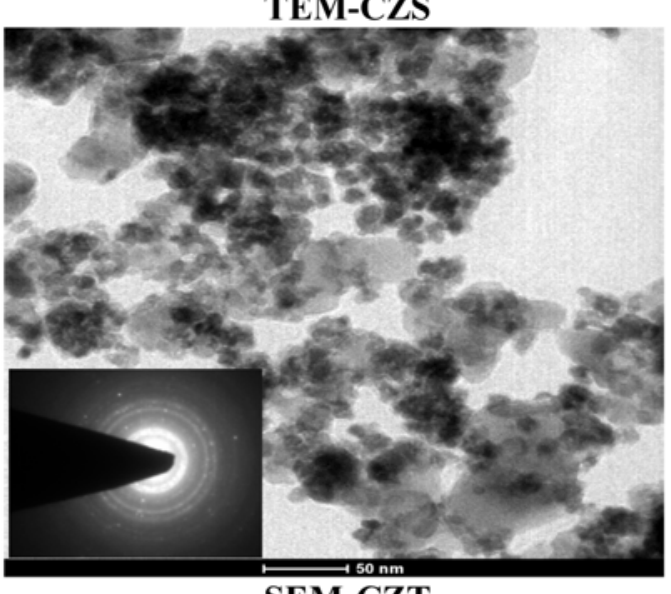

SEM-CZT

group, respectively [31].

XRD patterns of CZA, CZS, and CZT catalysts are shown in Fig. 4. The XRD peaks for CZA are found at $2 \theta$ angles of $28.629^{\circ}, 33.042^{\circ}$, $47.577^{\circ}$ and $56.545^{\circ}$ corresponding to (111), (200), (220) and (311) planes, respectively, and representing face centered cubic lattice. The XRD pattern of CZA indicates the presence of $\mathrm{CeO}_{2}$ (PDFICDD 001-0800), $\mathrm{Al}_{2} \mathrm{O}_{3}$ (PDF-ICDD 004-00879), $\mathrm{ZnO}$ (PDF-ICDD 003-0888) and spinel form of $\mathrm{CeAlO}_{3}$ (PDF-ICDD 021-0175). The XRD peaks for CZS are found at $2 \theta$ angles of $28.804^{\circ}, 33.267^{\circ}, 47.451^{\circ}$ and $56.594^{\circ}$ corresponding to (111), (002), (022) and (113) planes, 

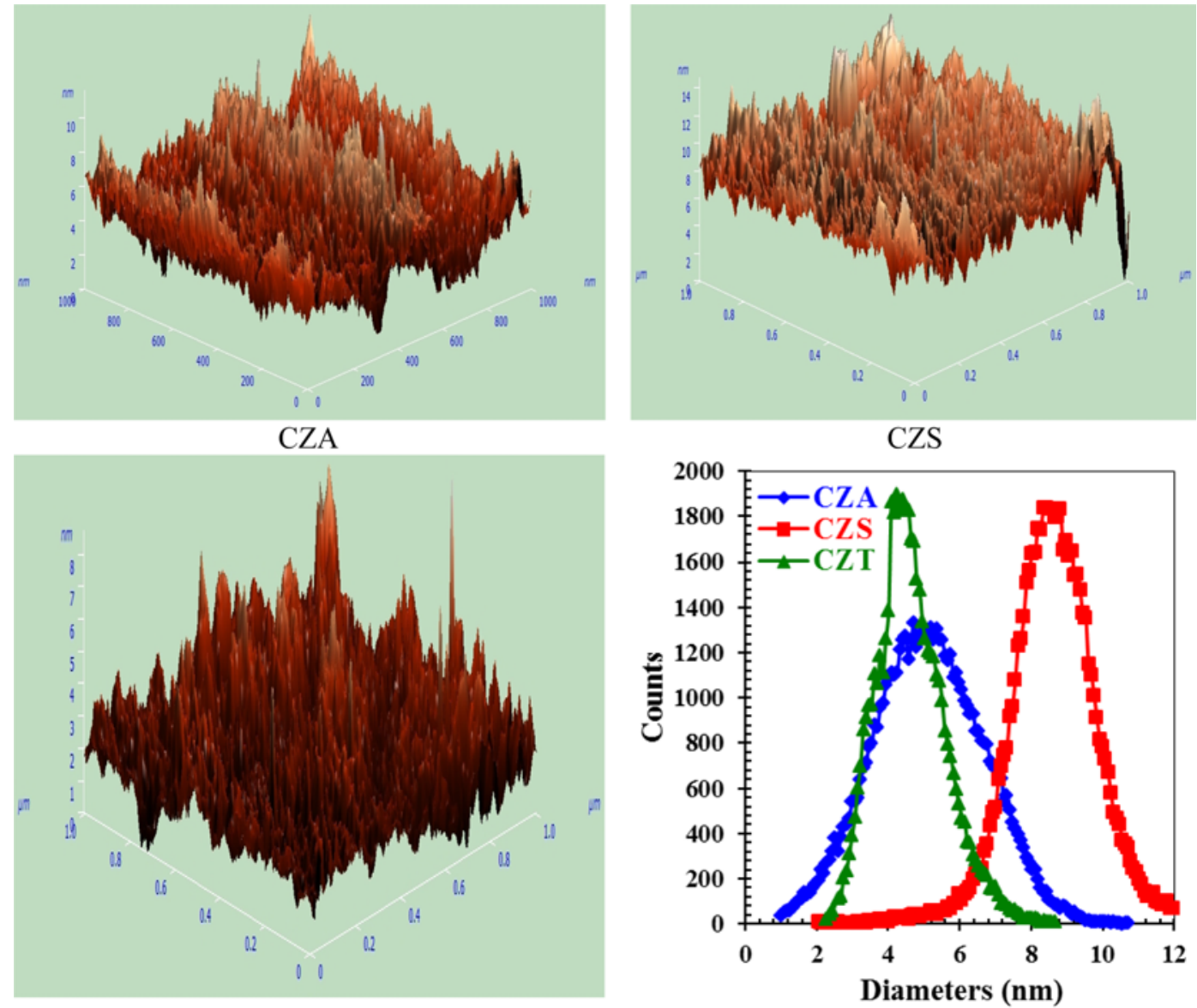

CZT

Histogram of Catalysts

Fig. 2. 3D AFM - image and histogram of CZA, CZS and CZT catalysts.

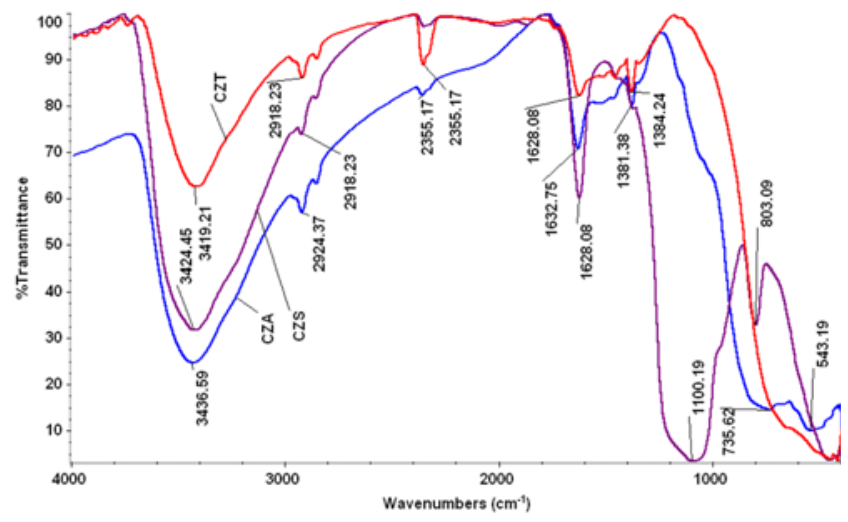

Fig. 3. FTIR spectra of CZA, CZS and CZT catalysts.

respectively, and representing face centered cubic lattice. These peaks indicates presence of $\mathrm{ZnO}$ (PDF-ICDD 00-003-0752), $\mathrm{CeO}_{2}$ (PDFICDD 00-002-1306), $\mathrm{SiO}_{2}$ (PDF-ICDD 008-0018), $\mathrm{Ce}_{2} \mathrm{Si}_{2} \mathrm{O}_{7}$ (PDFICDD 048-1588) and $\mathrm{Zn}_{2} \mathrm{SiO}_{4}$ (PDF-ICDD 002-0813) in CZS. The $\mathrm{XRD}$ peaks for CZT catalyst are seen at $2 \theta$ angle of $25.227^{\circ}, 28.569^{\circ}$, $33.165^{\circ}, 47.894^{\circ}$, and $56.58^{\circ}$ corresponding to (111), (200), (210), (311) and (330) plane, respectively. $\mathrm{CeO}_{2}$ (PDF-ICDD 001-0800), $\mathrm{ZnO}$ (PDF-ICDD 003-0752), $\mathrm{TiO}_{2}$ (PDF-ICDD 001-0562) and $\mathrm{Zn}_{4} \mathrm{TiO}_{6}$

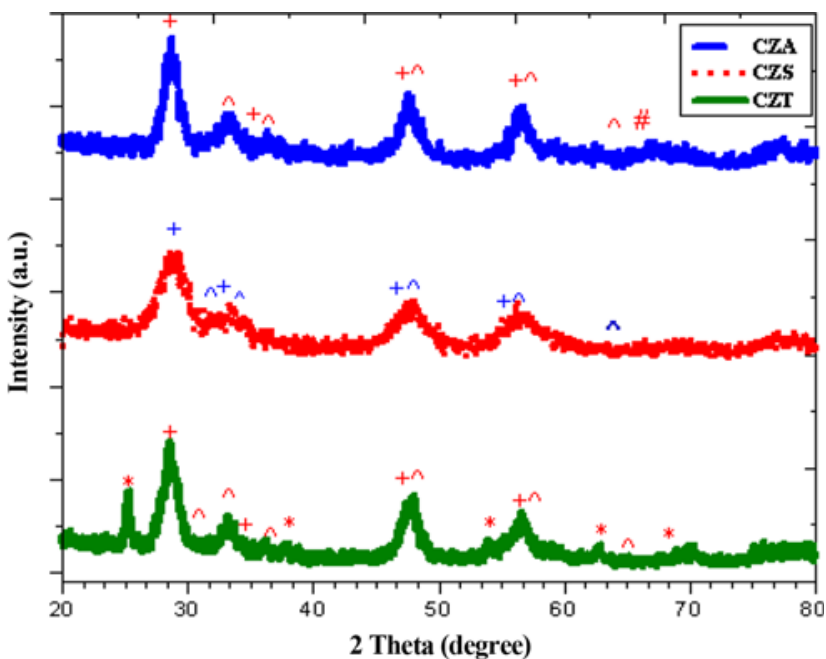

Fig. 4. XRD patterns of CZA, CZS, and CZT catalysts at $500{ }^{\circ} \mathrm{C}$. (+) Lines due to $\mathrm{CeO}_{2} ;(\wedge)$ lines due to $\mathrm{ZnO}$; (\#) lines due to $\gamma$ $\left.\mathrm{Al}_{2} \mathrm{O}_{3} ;{ }^{*}\right)$ lines due to $\mathrm{TiO}_{2}$ anatase.

(PDF-ICDD 049-0687) are found to be present on CZT [32,33]. All the CZA, CZS and CZT catalysts exhibited the mixed peaks of $\mathrm{ZnO}$ and $\mathrm{CeO}_{2}$ phases. Fig. 4 also shows that the individual peak 
Table 2. Crystallite size and textural properties of CZA, CZS and CZT catalysts

\begin{tabular}{|c|c|c|c|c|c|c|c|}
\hline \multirow[b]{2}{*}{ Catalyst } & \multicolumn{3}{|c|}{$\mathrm{XRD}$} & \multicolumn{3}{|c|}{ Textural properties } & \multirow[b]{2}{*}{$\begin{array}{c}\text { Maximum } \\
\text { yield (\%) }\end{array}$} \\
\hline & $\begin{array}{c}\text { Unit cell } \\
\text { parameter }(\AA)^{a}\end{array}$ & $\begin{array}{l}\text { Crystallite } \\
\text { size }(\mathrm{nm})^{a}\end{array}$ & Structure $^{a}$ & $\begin{array}{c}\text { Surface area } \\
\left(\mathrm{m}^{2} / \mathrm{g}\right)\end{array}$ & $\begin{array}{l}\text { Pore volume } \\
\left(\mathrm{cm}^{3} / \mathrm{g}\right)^{b}\end{array}$ & $\begin{array}{c}\text { Average pore } \\
\text { diameter }(\mathrm{nm})^{c}\end{array}$ & \\
\hline $\mathrm{CZA}$ & 5.42 & 3.70 & Cubic & 77 & 0.150 & 7.5 & 68 \\
\hline CZS & 6.29 & 3.90 & Cubic & 104 & 0.187 & 6.3 & 77 \\
\hline CZT & 5.38 & 3.05 & Cubic & 61 & 0.108 & 6.4 & 23 \\
\hline
\end{tabular}

${ }^{a}$ The unit cell parameter, crystal size and structure is calculate using XRD

${ }^{b} \mathrm{BJH}$ desorption cumulative pore volume of pores in the range 17 to $3,000 \AA$

${ }^{c} \mathrm{BJH}$ desorption average pore diameter

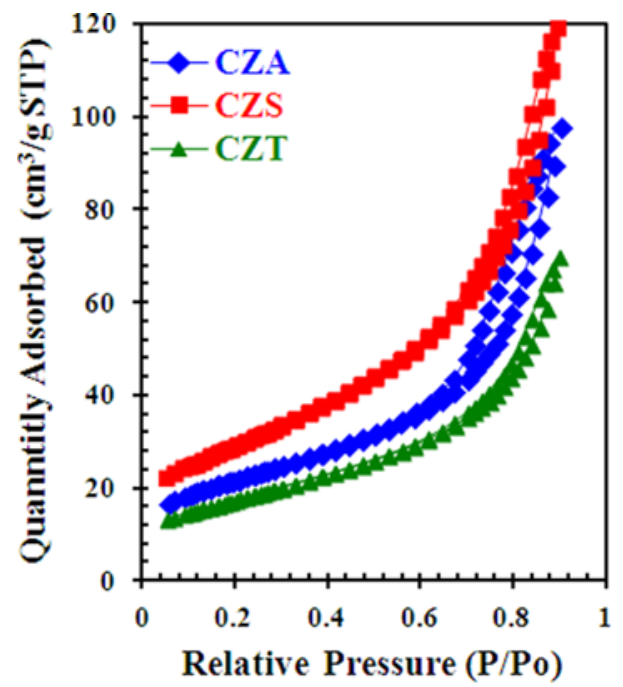

(a)

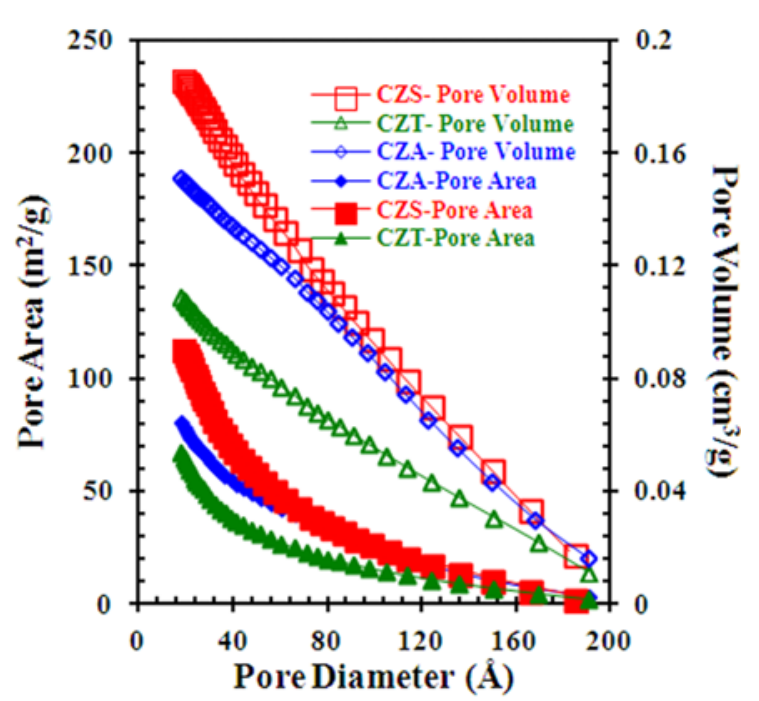

(b)

Fig. 5. (a) Adsorption/desorption isotherms of $\mathrm{N}_{2}$ at $77 \mathrm{~K}$; (b) pore size distribution for CZA, CZS and CZT catalysts.

positions for $\mathrm{CeO}_{2}$ and $\mathrm{ZnO}$ remain intact in the composite oxides. This is an indication that the composite oxides contain individual phases of $\mathrm{ZnO}, \mathrm{CeO}_{2}$ and some spinel forms of $\mathrm{Zn}$, Ce with their supports. The $\mathrm{CeO}_{2}$ peaks for catalysts CZA, CZS and CZT have been used in Scherrer's equation to calculate the crystallite size of ceria using $\mathrm{X}$-ray line broadening analysis. The data is summarized in Table 2. It is observed that the $\gamma-\mathrm{Al}_{2} \mathrm{O}_{3}, \mathrm{SiO}_{2}$ and $\mathrm{TiO}_{2}$ affect the particle size of ceria.

1-2. Textural Properties

The BET surface area, pore size distribution and pore volume as obtained from the corresponding instruments are given in Fig. 5 and Table 2 . The synthesized catalysts have surface area in the range of $61-104 \mathrm{~m}^{2} / \mathrm{g}$. The adsorption-desorption isotherms of the catalysts at $77.2 \mathrm{~K}$ confirm the generation of mesopores during their synthesis and the absence of micropores as shown in Fig. 5. All the adsorption-desorption isotherms are of type III, according to the IUPAC interpretation and exhibit an H3 hysteresis loop [34,35]. This confirms the presence of mesopores and absence of micropores in the synthesized catalysts. If the relative pressure increases $\left(\mathrm{P} / \mathrm{P}_{o}>0.60\right)$, then the isotherms show the capillary condensation of nitrogen within the uniform mesopores, where the $\mathrm{P} / \mathrm{P}_{o}$ position of the influence points is related to the diameter of the mesopores [36]. Among silica, alumina and titania supports, the specific surface is as follows: silica>alumina>titania [37]. Therefore, metal oxides impregnated on these supports also follow the same trend. Borgmann and Wedler [38] have reported similar trend of BET surface area for cobalt supported impregnated silica, aluminum and titania catalysts. Reddy et al. [25] also observed similar BET surface area trend for aluminum, silica and titania supported ceriazirconia catalyst.

The fractal dimension, often used as an index for estimating the irregularity or roughness of the catalyst surface, was studied using the Frenkel-Halsey-Hill (FHH) equation [39] for the CZA, CZS and CZT catalysts, to the adsorption isotherm of $\mathrm{N}_{2}$ [40]:

$$
\frac{\mathrm{q}}{\mathrm{q}_{e}}=\mathrm{K} \ln \left(\frac{\mathrm{P}_{o}}{\mathrm{P}}\right)^{D-3}
$$

where, $\mathrm{q}$ is the amount adsorbed at equilibrium pressure $\mathrm{P}, \mathrm{P}_{o}$ is the saturated pressure, $\mathrm{D}$ is the fractal dimension, $\mathrm{q}_{e}$ is the amount adsorbed filling micropore volume and $\mathrm{K}$ is a constant. The logarithmic plot of $\left(\mathrm{q} / \mathrm{q}_{e}\right)$ versus $\left(\mathrm{P}_{o} / \mathrm{P}\right)$ showed linear behavior, and $\mathrm{D}$ was calculated from the slope $(\mathrm{D}-3)$ of the straight line. Surface smoothness, irregular nature or roughness depends upon the $\mathrm{D}$ value. If $\mathrm{D}=2$, then the surface is considered to be perfectly smooth, whereas if $\mathrm{D}=3$, then the surface is very irregular or very rough. For the synthesized catalysts, the fractal dimension was found to 


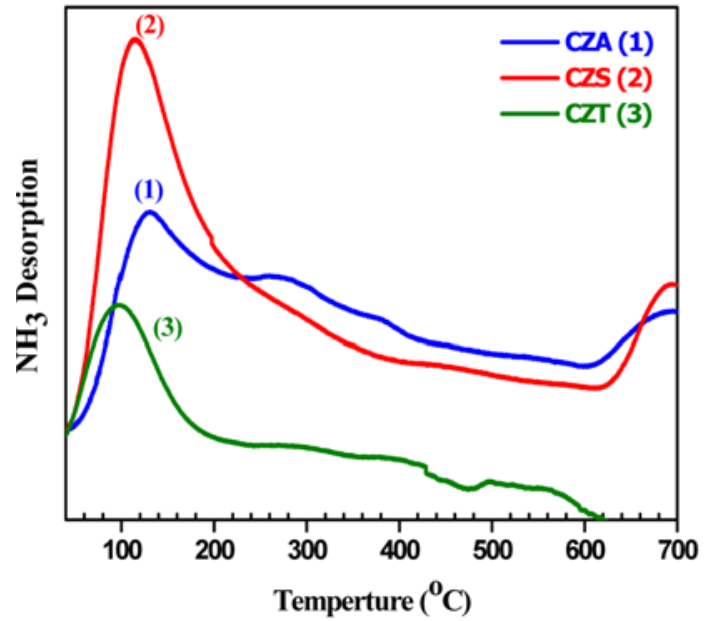

(a) $\mathrm{NH}_{3}$-TPD

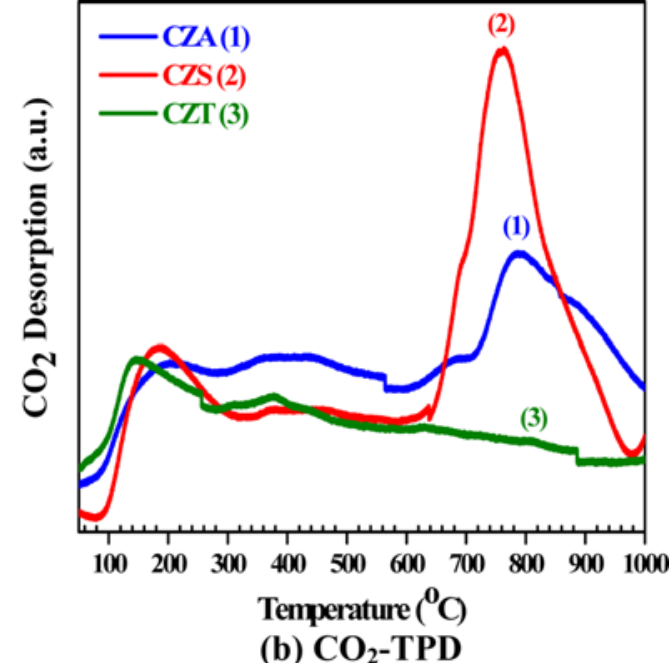

(b) $\mathrm{CO}_{2}$-TPD

Fig. 6. TPD profile of synthesized catalysts.

Table 3. TPD analysis using absorbed $\mathrm{NH}_{3}$ and $\mathrm{CO}_{2}$ for determining acidic and basic properties of synthesized catalysts

\begin{tabular}{|c|c|c|c|c|c|}
\hline \multirow{2}{*}{ Catalyst } & \multicolumn{3}{|c|}{ TPD analysis of absorbed $\mathrm{NH}_{3}(\mathrm{mmol} / \mathrm{g})$} & \multirow{2}{*}{$\begin{array}{l}\text { Total } \mathrm{NH}_{3} \text { evolved } \\
(\mathrm{mmol} / \mathrm{g})\end{array}$} & \multirow{2}{*}{$\begin{array}{l}\text { Acid site density } \\
\left(\mu \mathrm{mol} / \mathrm{m}^{2}\right)\end{array}$} \\
\hline & Weak $\left(<200^{\circ} \mathrm{C}\right)$ & Moderate $\left(200-450^{\circ} \mathrm{C}\right)$ & Strong $\left(>450^{\circ} \mathrm{C}\right)$ & & \\
\hline $\mathrm{CZA}$ & $0.691(131)$ & $0.116(282)$ & & 0.807 & 10.48 \\
\hline CZS & $1.288(113)$ & - & & 1.288 & 12.38 \\
\hline $\mathrm{CZT}$ & $0.343(99)$ & $0.001(296)$ & & 0.344 & 5.64 \\
\hline \multirow{2}{*}{ Catalyst } & \multicolumn{3}{|c|}{ TPD analysis of absorbed $\mathrm{CO}_{2}(\mathrm{mmol} / \mathrm{g})$} & Total $\mathrm{CO}_{2}$ evolved & Basic site density \\
\hline & Weak $\left(<200^{\circ} \mathrm{C}\right)$ & Moderate $\left(200-450{ }^{\circ} \mathrm{C}\right)$ & Strong $\left(>450{ }^{\circ} \mathrm{C}\right)$ & $(\mathrm{mmol} / \mathrm{g})$ & $\left(\mu \mathrm{mol} / \mathrm{m}^{2}\right)$ \\
\hline $\mathrm{CZA}$ & $0.242(177)$ & - & $0.795(796)$ & 1.037 & 13.47 \\
\hline CZS & 0.719 (188) & $0.151(459)$ & $1.951(763)$ & 2.821 & 27.12 \\
\hline $\mathrm{CZT}$ & $0.713(145)$ & - & - & 0.713 & 11.69 \\
\hline
\end{tabular}

Temperature $\left({ }^{\circ} \mathrm{C}\right)$ at maxima is given in brackets

be 2.514 for CZA, 2.441 for CZS and 2.511 for CZT. This shows the similarity of the surface heterogeneity among the synthesis catalysts, with a maximum deviation of $3 \%$.

1-3. $\mathrm{NH}_{3}$-TPD

To investigate the acid properties for the synthesized ceriumzinc with different supported catalysts, $\mathrm{NH}_{3}$-TPD analysis was performed [41]. $\mathrm{NH}_{3}$ desorption is temperature-dependent and can be classified in three stages: as weak $\left(<200{ }^{\circ} \mathrm{C}\right)$, moderate $\left(200-450{ }^{\circ} \mathrm{C}\right)$ and strong $\left(>450^{\circ} \mathrm{C}\right)$. Profiles of $\mathrm{NH}_{3}-\mathrm{TPD}$ on the supported CeZn catalysts are shown in Fig. 6(a), and the acidity of catalysts calculated from $\mathrm{NH}_{3}$-TPD peak area is summarized in Table 3. Two $\mathrm{NH}_{3}$ desorption peaks at $131{ }^{\circ} \mathrm{C}$ and $282^{\circ} \mathrm{C}$ were observed for CZA. Intensity of the peak is $0.691 \mathrm{mmol} / \mathrm{g}$ at $131{ }^{\circ} \mathrm{C}$ and $0.116 \mathrm{mmol} / \mathrm{g}$ at $282{ }^{\circ} \mathrm{C}$. These peaks could be ascribed to the desorption of $\mathrm{NH}_{3}$ from weak and moderate Lewis acid sites, respectively. CZS catalyst showed $\mathrm{NH}_{3}$ desorption peaks at $113{ }^{\circ} \mathrm{C}$ with $1.288 \mathrm{mmol} / \mathrm{g}$ intensity corresponding to weak Lewis acid site only. CZT catalyst showed the $\mathrm{NH}_{3}$ desorption peaks at $99^{\circ} \mathrm{C}$ with an intensity of 0.344 $\mathrm{mmol} / \mathrm{g}$ in the weak region only. According to $\mathrm{NH}_{3}-\mathrm{TPD}$ results, the total acidity of the synthesized CZA, CZS and CZT catalysts was $0.807 \mathrm{mmol} / \mathrm{g}, 1.288 \mathrm{mmol} / \mathrm{g}$ and $0.344 \mathrm{mmol} / \mathrm{g}$, respectively.

\section{1-4. $\mathrm{CO}_{2}$-TPD}

The profiles of $\mathrm{CO}_{2}$-TPD of the synthesized Ce- $\mathrm{Zn}$ with supported catalysts are shown in Fig. 6(b) and the basicity of the catalysts calculated form $\mathrm{CO}_{2}$-TPD peak area is summarized in Table 3 . The $\mathrm{CO}_{2}$-TPD can be classified as weak $\left(<200^{\circ} \mathrm{C}\right)$, moderate $(200$ $450^{\circ} \mathrm{C}$ ) and strong $\left(>450^{\circ} \mathrm{C}\right)$. CZT catalyst showed only weak basicity observed by peak around $145^{\circ} \mathrm{C}$. CZA catalyst shows two distinct peaks at $242^{\circ} \mathrm{C}$ and $796^{\circ} \mathrm{C}$ in the moderate and strong region, respectively. For CZS catalyst, peaks are observed in all the three regions at 188,459 and $763{ }^{\circ} \mathrm{C}$. According to the $\mathrm{CO}_{2}$-TPD results, CZS catalyst showed strong, moderate, and weak basic sites, with intensities of $1.951 \mathrm{mmol} / \mathrm{g}, 0.151 \mathrm{mmol} / \mathrm{g}$ and $0.719 \mathrm{mmol} / \mathrm{g}$, respectively, and the total basic amount being $2.821 \mathrm{mmol} / \mathrm{g}$. CZA showed desorption behavior at strong $\left(>450{ }^{\circ} \mathrm{C}\right)$ and weak basic sites $\left(<200^{\circ} \mathrm{C}\right)$ with the basic amount being $0.795 \mathrm{mmol} / \mathrm{g}$ and $0.242 \mathrm{mmol} / \mathrm{g}$, respectively. CZT catalyst showed only weak basic sites with intensity of $0.823 \mathrm{mmol} / \mathrm{g}$.

Silanol groups in amorphous silica provide weak Brønsted acidity. Calcination of silica increases the Lewis acidity and basicity due to activation of siloxane groups by dehydration reaction. In comparison, alumina and titania supports develop lower amount 
of Lewis acidity and basicity during their calcination [35]. Synthesized Ce-Zn have both acidic and basic sites, indicating that the catalysts can act as acid-base bifunctional catalysts; however, support materials varied the nature of the catalysts. A few investigators have reported that the presence of both acidic and basic sites helps in the transesterification of PC with methanol used for DMC synthesis $[17,20]$.

1-5. Thermal Stability

Thermal stability of the synthesized catalysts was determined by thermogravimetric analysis. TGA, differential thermal gravimetry (DTG), differential thermal analysis (DTA) traces of the CZA, CZS and CZT catalysts are shown in Fig. S2. TGA traces show mass loss of 7.3\%, $8.03 \%$ and $4.4 \%$ for CZA, CZS and CZT catalysts, respectively, in the temperature range of $20-200^{\circ} \mathrm{C}$. These mass losses may be due to vaporization of low boiling point organic molecules including moisture. Mass loss of $8 \%$ for CZA,8.3\% for CZS and $6.9 \%$ for CZT was observed in the range of $200-500{ }^{\circ} \mathrm{C}$. At $1,000^{\circ} \mathrm{C}$, the catalyst samples retained residual mass of $84.7 \%, 83.7 \%$ and $88.7 \%$ of the original mass for CZA, CZS and CZT catalysts, respectively. Thus, all the catalysts were highly thermally stable.

\section{Catalytic Activity for DMC Synthesis}

The catalytic activity of the cerium-zinc oxide stabilized on the three supports was tested for the transesterification of PC with methanol. The activity measurement was performed at the initial pressure of 2-5 bar and the final pressure of 20-25 bar. One mol of PC reacts with two moles of methanol to produce one mole of DMC and one mole of PG. However, an excess amount of methanol drives the reaction towards the transesterified product.

The effect of temperature on the synthesis of DMC was investigated over the temperature range of $120-200{ }^{\circ} \mathrm{C}$. The results are shown in Fig. 7(a). Maximum DMC yield of $77 \%$ was obtained at $170{ }^{\circ} \mathrm{C}$ for CZS catalyst, whereas CZA and CZT gave $68 \%$ and $23 \%$ $\mathrm{DMC}$ yield, respectively at $170^{\circ} \mathrm{C}$. The $\mathrm{DMC}$ yield increases with an increase in temperature up to $170^{\circ} \mathrm{C}$ and, thereafter decreases with an increase in the reaction temperature. At all temperatures more than $170^{\circ} \mathrm{C}$, side reactions and/or decomposition of DMC to PC and formation of the byproduct PG are observed. The optimum synthesis temperature for DMC was $170{ }^{\circ} \mathrm{C}$, giving an optimum yield of $77 \%$ with CZS catalyst. The optimum reaction temperature for transesterification of PC with methanol for DMC synthesis were reported to be $160^{\circ} \mathrm{C}$ by Wang et al. [22] and Wei et al. [17]. Srivastava et al. [20] reported $170{ }^{\circ} \mathrm{C}$ as the optimum temperature.

The effect of molar ratio of methanol/PC on the synthesis of DMC using the three catalysts is shown in Fig. 7(b). It is found that the DMC yield increases with an increases the mole ratio of methanol/ PC. Maximum DMC yield is observed at a methanol/PC molar ratio of 10 for all the catalysts. When the molar ratio of methanol/PC is lower, the side reaction forming PG takes place, thereby adversely affecting the DMC formation. Higher methanol/PC ratio shifts the equilibrium towards the product side [40]. The DMC yield reaches a maximum of $77 \%, 69 \%$ and $23 \%$ for CZS, CZA and CZT, respectively, for the molar ratio of 10 for methanol/PC. Srivastava et al. [20] Unnikrishnan and Srinivas [24] Murugan et al. [42] and Kumar et al. [43] reported a methanol/PC molar ratio of 10 as the optimum ratio for the transesterification $\mathrm{PC}$ with methanol for the synthesis of DMC using Fe- $\mathrm{Zn}$ double-metal cyanide, earth promoted $\mathrm{Mg}$ $\mathrm{Al}$ hydrotelcite and $\mathrm{KF} / \mathrm{Al}_{2} \mathrm{O}_{3}$ catalysts, respectively.

A possible mechanism for the synthesis of DMC from PC with methanol is represented in Scheme $1[17,44]$. Methanol gets activated in the presence of the catalysts to form $\mathrm{H}^{+}$and $\mathrm{CH}_{3} \mathrm{O}^{-} ; \mathrm{CH}_{3} \mathrm{O}$ attracts the carbonyl $\mathrm{C}$ of the $\mathrm{PC}$ and forms $\mathrm{CH}_{3} \mathrm{O}-\mathrm{CO}-\mathrm{O}-\mathrm{CH}_{2}-$ $\mathrm{CH}\left(\mathrm{CH}_{3}\right)-\mathrm{O}^{-}$as an intermediate, which further reacts with $\mathrm{H}^{+}$to form an intermediate, $\mathrm{CH}_{3} \mathrm{O}-\mathrm{CO}-\mathrm{O}-\mathrm{CH}_{2}-\mathrm{CH}\left(\mathrm{CH}_{3}\right)-\mathrm{OH}$ (2-methylhydroxyethyl methyl carbonate). This intermediate further reacts with $\mathrm{CH}_{3} \mathrm{O}^{-}$to form DMC and intermediate, $\mathrm{OH}-\mathrm{CH}_{3}-\mathrm{CH}_{2}-\mathrm{CH}_{2}-\mathrm{O}^{-}$ which reacts with $\mathrm{H}^{+}$to form $\mathrm{PG}$. The overall reaction of $\mathrm{PC}$ with methanol for the synthesis of DMC reaction is exothermic [16]. The main function of the solid basic catalyst is its activation with methanol through the abstraction of $\mathrm{H}^{+}$by the acid site so as to form $\mathrm{CH}_{3} \mathrm{O}^{-}$which reacts with $\mathrm{PC}$ to produce DMC. The higher
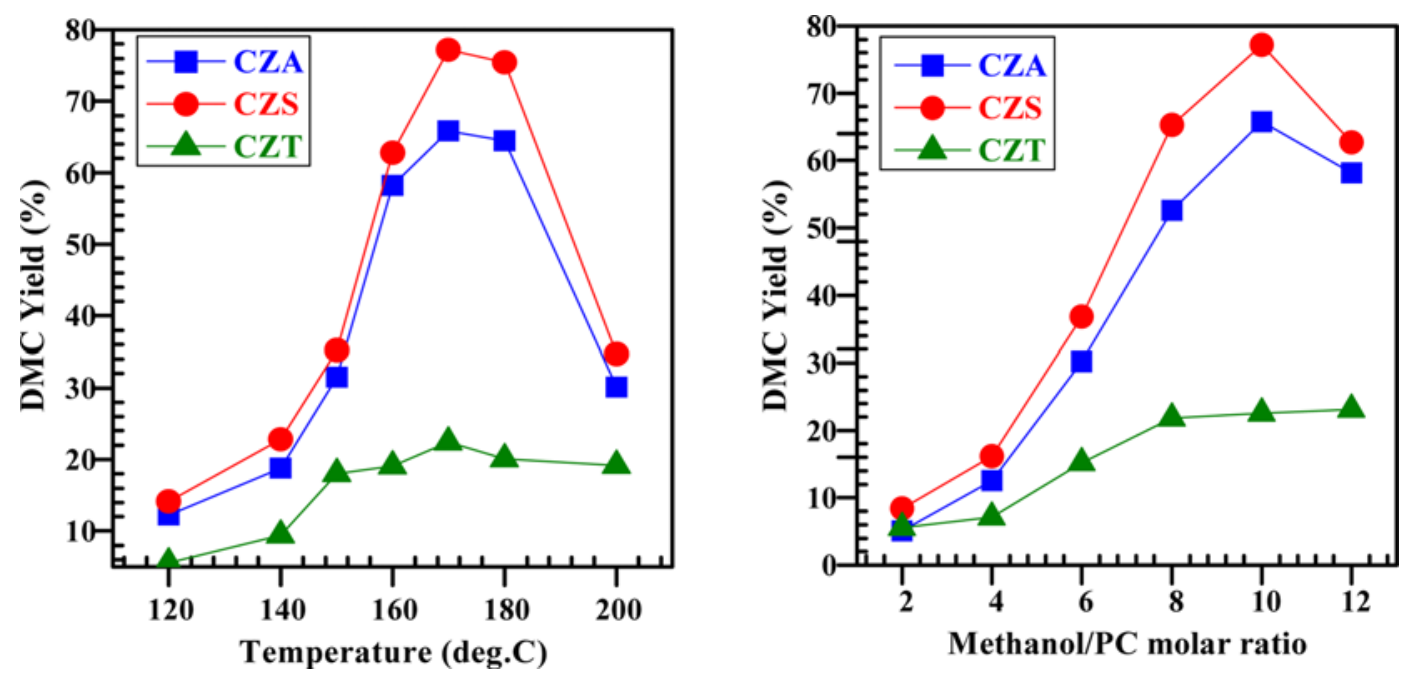

Fig. 7. (a) Effect on reaction temperature on DMC formation using different catalysts; (b) effect on PC to methanol molar ratio on synthesis of DMC using different catalysts at temperature $170^{\circ} \mathrm{C}$ (reaction condition: $\mathrm{PC}=0.25 \mathrm{~mol}$, methanol $=2.5 \mathrm{~mol}$, catalyst $=5 \mathrm{wt} \%$ of reactant, reaction time $=4 \mathrm{~h}$ ). 
the basicity of the catalyst, the more negative is the charge of $\mathrm{MeO}^{-}$ and lower is the free energy of $\mathrm{MeO}^{-}$with PC.

Overall, CZS catalyst exhibited the best performance as compared to CZA and CZT catalysts. CZS has highest BET surface area, acidic and basic sites per unit mass of the catalyst. Moreover, acid site density (acidic sites per unit surface area) of the synthesized catalysts follow the sequence (Table 3): CZS $\left(12.38 \mu \mathrm{mol} / \mathrm{m}^{2}\right)>\mathrm{CZA}$ $\left(11.48 \mu \mathrm{mol} / \mathrm{m}^{2}\right)>$ CZT $\left(5.64 \mu \mathrm{mol} / \mathrm{m}^{2}\right)$. Similarly, the basic site density of the synthesized catalysts has the following sequence (Table 3): CZS $\left(27.12 \mu \mathrm{mol} / \mathrm{m}^{2}\right)>\mathrm{CZA}\left(13.47 \mu \mathrm{mol} / \mathrm{m}^{2}\right)>\mathrm{CZT}(11.69 \mu \mathrm{mol} /$ $\mathrm{m}^{2}$ ). Thus, the basic and acidic site densities and the catalytic activity followed a similar trend. CZS having higher basicity lowers the free energy of this reaction and enhances the yield of DMC by the transesterification reaction [17].

Juarez et al. [45] used a series of metal oxide nanoparticles namely $\mathrm{MgO}, \mathrm{ZrO}_{2}, \mathrm{CeO}_{2}$ and $\mathrm{Au} / \mathrm{CeO}_{2}(1.5 \mathrm{wt} \%)$ with acid or basic properties exhibit low to moderate activity towards the transesterification of PC with methanol. They reported that strongly basic $\mathrm{MgO}$ increases the PC conversion, however, for PC hydrolysis with very poor selectivity towards $\mathrm{DMC}$. $\mathrm{ZrO}_{2}$, which is an acid metal oxide, showed low PC with better selectivity towards DMC. $\mathrm{CeO}_{2}$ exhibited intermediate activity and selectivity towards DMC formation. Yield with $\mathrm{CeO}_{2}$ was much better than $\mathrm{MgO}$ and $\mathrm{ZrO}_{2}$ (in that order). Gold nanoparticles supported on nanocrystalline ceria $\left(\mathrm{Au} / \mathrm{CeO}_{2}\right)$ exhibited much higher PC conversion, DMC selectivity and yield than $\mathrm{CeO}_{2}$. Wang et al. [46] used zinc-yttrium based catalysts for synthesis of DMC via transesterification of ethyl carbonate (EC) with methanol. The yield of the DMC directly correlated well with the BET surface area and basicity of the catalysts. Cui et al. [47] studied synthesis of DMC through the transesterification of EC using $\mathrm{MgO}$ and mesoporous silica coated $\mathrm{MgO}\left(\mathrm{MgO}_{\mathrm{SiO}}\right)$ catalyst. BET surface area of $\mathrm{MgO}^{-} \mathrm{SiO}_{2}\left(412.6 \mathrm{~m}^{2} / \mathrm{g}\right)$ was much larger than that of the pure flower-like $\mathrm{MgO}\left(141.4 \mathrm{~m}^{2} / \mathrm{g}\right)$. With $\mathrm{MgO}$, EC conversion in the first run was $92 \%$, which dropped sharply to $52 \%$ in the second run, because of the stability issues. For MgO$\mathrm{SiO}_{2}, \mathrm{EC}$ conversion was constantly over $80 \%$ for 10 consecutive runs. Authors did not report basicity so it was not possible to correlate the results with basicity. $\mathrm{Xu}$ et al. [48] investigated various $\mathrm{CeO}_{2}$ based catalysts (with different surface areas and basicity) for transesterification of $\mathrm{EC}$ with methanol for $\mathrm{DMC}$ synthesis. Catalyst $\mathrm{CeO}_{2}$-meso$400\left(182 \mathrm{~m}^{2} / \mathrm{g}\right.$ and $\left.212 \mu \mathrm{mol} \mathrm{CO}_{2} / \mathrm{g}\right)$ had high surface area and high basicity as compared to $\mathrm{CeO}_{2}$-meso-500 $\left(149 \mathrm{~m}^{2} / \mathrm{g}\right.$ and $178 \mu \mathrm{mol}$ $\left.\mathrm{CO}_{2} / \mathrm{g}\right)$ and $\mathrm{CeO}_{2}$-meso-600 $\left(108 \mathrm{~m}^{2} / \mathrm{g}\right.$ and $\left.141 \mu \mathrm{mol} \mathrm{CO} / \mathrm{g}\right)$. The highest activity was observed with $\mathrm{CeO}_{2}$-meso-400 with $\mathrm{DMC}$ yield of $73.3 \%$ as compared to $\mathrm{CeO}_{2}$-meso-500 (63.8\%) and $\mathrm{CeO}_{2}$-meso$600(57.1 \%)$. Therefore, the basicity and BET surface area of the synthesized catalysts play an important role during DMC synthesis by transesterification reactions. The catalytic activity of the supported catalyst depends upon the support. The XRD patterns, $\mathrm{CO}_{2}$ TPD, SEM and BET surface area provide interesting information about the synthesized catalysts with different supports and used for the transesterification of PC with methanol to produce DMC.

\section{CONCLUSION}

Ceria and zinc oxide were impregnated onto various oxides sup- ports such as alumina $\left(\mathrm{Al}_{2} \mathrm{O}_{3}\right)$, silica $\left(\mathrm{SiO}_{2}\right)$ and titania $\left(\mathrm{TiO}_{2}\right)$ in the molar ratio of $1: 1: 2$ by deposition-coprecipitation method. Variation of support changed not only the structure and textural properties of the catalyst, but also the basic strength and basic sites of the catalyst. Acidity and basicity of the catalysts directly influence in the transesterification of PC with methanol. The prepared CZA, CZS and CZT catalyst showed good catalytic activity for the synthesis of DMC from methanol and PC. CZS catalysts had higher catalytic activity due to high basic strength and high BET surface area in comparison to CZA and CZT catalysts. Moreover, the basic strength supplied by the $\mathrm{SiO}_{2}$ also is improving the highest catalytic activity. DMC yield of $77 \%$ was observed with CZS catalyst under optimal conditions (temperature $=170^{\circ} \mathrm{C}$ and methanol/PC molar ratio $=1: 10$ ).

\section{SUPPORTING INFORMATION}

Additional information as noted in the text. This information is available via the Internet at http://www.springer.com/chemistry/ journal/11814.

\section{REFERENCES}

1. N. Keller, G. Rebmann and V. Keller, J. Mol. Catal. A: Chem., 317, 1 (2010).

2. Y. Ono, Appl. Catal. A: Gen., 155, 133 (1997).

3. D. Delledonne, F. Rivetti and U. Romano, Appl. Catal. A: Gen., 221, 241 (2001).

4. P. Lu, H. Wang and K. Hu, Chem. Eng. J., 228, 147 (2013).

5. M. G. Alvarez, A. Segarra, S. Contreras, J.E. Sueiras, F. Medina and F. Figueras, Chem. Eng. J., 161, 340 (2010).

6. X. He, Z. Li, K. Su, B. Cheng and J. Ming, Catal. Commun., 33, 20 (2013).

7. Z. Li, B. Cheng, K. Su, Y. Gu, P. Xi and M. Guo, J. Mol. Catal. A: Chem., 289, 100 (2008).

8. R. Xia, Z. Li, B. Cheng and K. Su, Korean J. Chem. Eng., 31, 427 (2014).

9. H. J. Lee, W. Joe and I. K. Song, Korean J. Chem. Eng., 29, 317 (2012).

10. H. J. Lee, W. Joe, J. C. Jung and I. K. Song, Korean J. Chem. Eng., 29, 1019 (2012).

11. V. Eta, P. M. Arvela, A. R. Leino, K. Kordàs T. Salmi, D. Y. Murzin and J. P. Mikkola, Ind. Eng. Chem. Res., 49, 9609 (2010).

12. H. J. Lee, S. Park, I. K. Song and J.C. Jung, Catal. Lett., 141, 531 (2011).

13. W. Joe, H. J. Lee, U. G. Hong, Y. S. Ahn, C. J. Song, B. J. Kwon and I. K. Song, J. Ind. Eng. Chem., 29, 1019 (2012).

14. D. Wang, X. Zhang, Y. Gao, F. Xiao, W. Wei and Y. Sun, Fuel Process. Technol., 91, 1081 (2010).

15. W. Zhao, W. Peng, D. Wang, N. Zhao, J. Li, F. Xiao, W. Wei and Y. Sun, Catal. Commun., 10, 655 (2009).

16. A. Pyrlik, W. F. Hoelderich, K. Müller, W. Arlt, J. Strautmann and D. Kruse, Appl. Catal. B: Environ., 125, 486 (2012).

17. T. Wei, M. Wang, W. Wei, Y. Sun and B. Zhong, Fuel Process. Technol., 83, 175 (2003).

18. Z. Z. Yang, L. N. He, X. Y. Dou and S. Chanfreau, Tetrahedron Lett., 51, 2931 (2010). 
19. H. Wang, M. Wang, W. Zhang, N. Zhao, W. Wei and Y. Sun, Catal. Today, 115, 107 (2006).

20. R. Srivastava, D. Srinivas and P. Ratnasamy, J. Catal., 241, 34 (2006).

21. E. S. Jeong, K. H. Kim, D. W. Park, S. W. Park and J. W. Lee, Reac. Kinet. Catal. Lett., 86, 241 (2005).

22. H. Wang, M. Wang, S. Liu, N. Zhao, W. Wei and Y. Sun, J. Mol. Catal. A: Chem., 258, 308 (2006).

23. S. Liu, S. Huang, L. Guan, J. Li, N. Zhao, W. Wei and Y. Sun, Micropor. Mater., 102, 304 (2007).

24. P. Unnikrishnan and D. Srinivas, Ind. Eng. Chem. Res., 51, 6356 (2012).

25. B. M. Reddy, P. Saikia and P. Bharali, Catal. Surv. Asia, 12, 214 (2008).

26. S. Brunauer, P. H. Emmet and F. Teller, J. Am. Chem. Soc., 60, 309 (1938).

27. E. P. Barret, L. G. Joyner and P. P. Hanlenda, J. Am. Chem. Soc., 73, 373 (1951).

28. Y. He, X. Yu, T. Li, L. Yan and B. Yang, Powder Technol., 166, 72 (2006).

29. D. Sarkar, D. Mohapatra, S. Ray, S. Bhattacharyya, S. Adak and N. Mitra, Ceram. Int., 33, 1275 (2007).

30. P. R. Potti and V. C. Srivastava, Ind. Eng. Chem. Res., 51, 7948 (2012).

31. H. Cui, M. Zayat and D. Levy, Chem. Mater., 17, 5562 (2005).

32. L. Samiee, A. Beitollahi and A. Vinu, Res. Chem. Intermed., 38, 1467 (2012).

33. L. Samiee and A. Beitollahi, DOI:10.1007/s11164-013-1329-3.

34. K. S. W. Sing, D. H. Everett, R. A. W. Haul, L. Moscou, R. A. Pierotti,
J. Rouquérol and T. Siemieniewska, Pure Appl. Chem., 57, 603 (1985).

35. J. Rouquérol, J. H. Avnir, C. W. Fairbridge, D. H. Everett, J. H. Haynes, N. Pernicone, J. D. F. Ramsay, K. S. W. Sing and K. K. Unger, Pure Appl. Chem., 66, 1739 (1994).

36. L. Samiee, F. Shoghi and A. Vinu, Appl. Surf. Sci., 265, 214 (2013).

37. M. Grun, A. A. Kurgabov, S. Schacht, F. Schuth and K. K. Unger, J. Chromatogr. A., 740, 1 (1996).

38. M. V. D. Borgmann and G. Wedler, J. Catal., 212, 10 (2002).

39. G. D. Halsey, J. Chem. Phys., 16, 931 (1948).

40. M. Sato, T. Sukegawa, T. Suzuki and K. Kaneko, J. Phys. Chem. B., 101, 1845 (1997).

41. K. Tanabe, M. Misono, Y. Ono and H. Hattori, Stud. Surf. Sci. Catal., 51, 5 (1989).

42. C. Murugan, H. C. Bajaj and R. V. Jasra, Catal. Lett., 137, 224 (2010).

43. P. Kumar, V. C. Srivastava and I. M. Mishra, Catal. Commun., 60, 27 (2015).

44. J. Xu, H. T. Wu, C. M. Ma, B. Xue, Y. X. Li and Y. Cao, Appl. Catal. A: Gen., 464-465, 357 (2013).

45. R. Juarez, A. Corma and H. Garcia, Green Chem., 949-952, 11 (2009).

46. L. Wang, Y. Wang, S. Liu, L. Lu, X. Ma and Y. Deng, Catal. Commun., 45-49, 16 (2011).

47. Z.-M. Cui, Z. Chen, C.-Y. Cao, W.-G Song and L. Jiang, Chem. Commun., 6093-6095, 49 (2013).

48. J. Xu, K.-Z. Long, F. Wu, B. Xue, Y.-X. Li and Y. Cao, Appl. Catal. A: Gen., 1-7, 484 (2014). 


\title{
Supporting Information
}

\section{Dimethyl carbonate synthesis via transesterification of propylene carbonate with methanol by ceria-zinc catalysts: Role of catalyst support and reaction parameters}

\author{
Praveen Kumar, Vimal Chandra Srivastava ${ }^{\dagger}$, and Indra Mani Mishra
}

Department of Chemical Engineering, Indian Institute of Technology Roorkee, Roorkee 247667, Uttarakhand, India (Received 26 December 2014 - accepted 16 February 2015)

Table S1. Literature review on characterization of of ceria-zinc based catalysts for various applications

\begin{tabular}{|c|c|c|c|c|c|c|c|c|c|c|c|}
\hline \multirow{2}{*}{$\begin{array}{l}\text { Characterization } \\
\text { technique }\end{array}$} & $\begin{array}{l}\text { Xie et } \\
\text { al. [27] }\end{array}$ & $\begin{array}{l}\text { Rajgure } \\
\text { et al. [28] }\end{array}$ & $\begin{array}{l}\text { Mi et } \\
\text { al. [29] }\end{array}$ & $\begin{array}{l}\text { Joe et al. } \\
{[22]}\end{array}$ & $\begin{array}{l}\text { Zhong } \\
\text { et al. [30] }\end{array}$ & $\begin{array}{l}\text { Ying et } \\
\text { al. [31] }\end{array}$ & $\begin{array}{l}\text { Wang et } \\
\text { al. [32] }\end{array}$ & $\begin{array}{l}\text { Ma et } \\
\text { al. [33] }\end{array}$ & $\begin{array}{l}\text { Mishra } \\
\text { and Rao } \\
{[34]}\end{array}$ & $\begin{array}{l}\text { He et } \\
\text { al. [35] }\end{array}$ & This work \\
\hline & $\begin{array}{l}\mathrm{CeO}_{2^{-}} \\
\mathrm{ZnO}\end{array}$ & $\begin{array}{l}\mathrm{CeO}_{2-}^{-} \\
\mathrm{ZnO}\end{array}$ & $\begin{array}{l}\mathrm{Ce}- \\
\mathrm{ZnF}_{2} \mathrm{O}_{3}\end{array}$ & $\begin{array}{l}\mathrm{ZnO}(\mathrm{X})- \\
\mathrm{CeO}_{2} \\
(1-\mathrm{X})\end{array}$ & $\begin{array}{l}\mathrm{Ce}_{1-x} \\
\mathrm{Zn}_{x} \mathrm{O}_{2-\delta} \\
\text { oxide }\end{array}$ & $\begin{array}{l}\mathrm{Ce}_{1-x} \\
\mathrm{Zn}_{x} \mathrm{O}_{y}\end{array}$ & $\begin{array}{l}\mathrm{S}_{2} \mathrm{O}_{8}^{2-} / \mathrm{Al}_{-} \\
\text {wt } \% \\
\mathrm{Ce}-\mathrm{Zn}-\mathrm{O}\end{array}$ & $\begin{array}{l}\mathrm{ZnO}- \\
\mathrm{eO}_{2}\end{array}$ & $\begin{array}{l}\mathrm{CeO}_{2^{-}} \\
\mathrm{ZnO}\end{array}$ & $\begin{array}{l}\mathrm{CeO}_{2} / \\
\mathrm{ZnO}\end{array}$ & $\begin{array}{l}\mathrm{CeO}_{2}-\mathrm{ZnO} / \\
\text { support } \\
\mathrm{Al}_{2} \mathrm{O}_{3} / \mathrm{SiO}_{2} / \\
\mathrm{TiO}_{2}\end{array}$ \\
\hline $\mathrm{XRD}$ & $\mathrm{X}$ & $\mathrm{X}$ & $\mathrm{X}$ & $\mathrm{X}$ & $\mathrm{X}$ & $\mathrm{X}$ & $\mathrm{X}$ & $\mathrm{X}$ & $\mathrm{X}$ & $\mathrm{X}$ & $\mathrm{X}$ \\
\hline N2-sorption & $\mathrm{X}$ & & $\mathrm{X}$ & $\mathrm{X}$ & & & & $\mathrm{X}$ & & $\mathrm{X}$ & $\mathrm{X}$ \\
\hline SEM/EDS & $\mathrm{X}$ & $\mathrm{X}$ & $\mathrm{X}$ & & $\mathrm{X}$ & & $\mathrm{X}$ & $\mathrm{X}$ & $\mathrm{X}$ & $\mathrm{X}$ & $\mathrm{X}$ \\
\hline FTIR & $\mathrm{X}$ & & & & & & $\mathrm{X}$ & & & & $\mathrm{X}$ \\
\hline TPD-NH 3 & & & & $\mathrm{X}$ & & & & & $\mathrm{X}$ & & $\mathrm{X}$ \\
\hline $\mathrm{TPD}-\mathrm{CO}_{2}$ & & & & $\mathrm{X}$ & & & & & & $\mathrm{X}$ & $\mathrm{X}$ \\
\hline TEM & $\mathrm{X}$ & $\mathrm{X}$ & & & $\mathrm{X}$ & & & $\mathrm{X}$ & & & \\
\hline CHNS & & & & & & & & & $\mathrm{X}$ & & \\
\hline TPD-methanol & & & & & & $\mathrm{X}$ & & & & & \\
\hline Process & $\begin{array}{l}\mathrm{CO} \\
\text { oxida- } \\
\text { tion }\end{array}$ & $\begin{array}{l}\text { Gas } \\
\text { sensor }\end{array}$ & $\begin{array}{l}\text { Desul- } \\
\text { furiza- } \\
\text { tion }\end{array}$ & $\begin{array}{l}\text { Urea } \\
\text { methano- } \\
\text { lysis }\end{array}$ & $\begin{array}{l}\mathrm{CO} O \mathrm{Oxi}- \\
\text { dation }\end{array}$ & $\begin{array}{l}\text { Oxidative } \\
\text { stem } \\
\text { reforming }\end{array}$ & $\begin{array}{l}\text { Esterifica- } \\
\text { tion }\end{array}$ & $\begin{array}{l}\text { Photo- } \\
\text { catalytic } \\
\text { oxidation }\end{array}$ & $\begin{array}{l}\text { Cyclohexa- } \\
\text { nol dehy- } \\
\text { drogenation }\end{array}$ & $\begin{array}{l}\text { Oxidat- } \\
\text { tive reac- } \\
\text { tion of } \\
\mathrm{CO}_{2}\end{array}$ & Synthesis \\
\hline End products & $\begin{array}{l}\mathrm{CO}_{2} \\
\mathrm{H}_{2} \\
\mathrm{H}_{2} \mathrm{O}\end{array}$ & & & $\begin{array}{l}\text { Dimethyl } \\
\text { carbonate }\end{array}$ & $\begin{array}{l}\mathrm{CO}_{2}, \mathrm{H}_{2}, \\
\mathrm{H}_{2} \mathrm{O}\end{array}$ & Hydrogen & $\begin{array}{l}\text { n-Butyl } \\
\text { acetate }\end{array}$ & & & $\begin{array}{l}\mathrm{C}_{2} \text { Hydro- } \\
\text { carbons }\end{array}$ & $\begin{array}{l}\text { Dimethyl } \\
\text { carbonate }\end{array}$ \\
\hline
\end{tabular}

$\mathrm{X}$ denotes that particular study reported in the study 


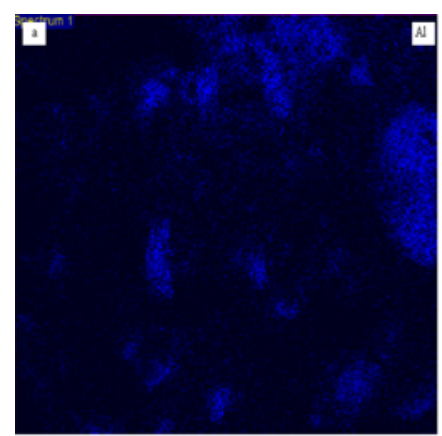

Al

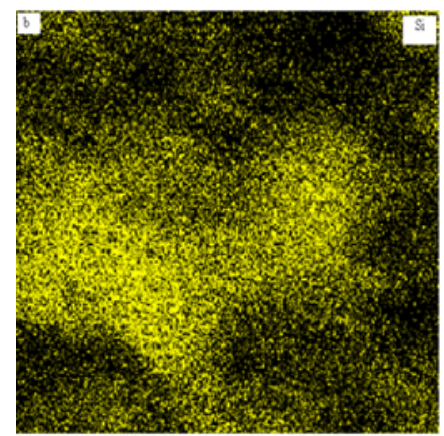

Si

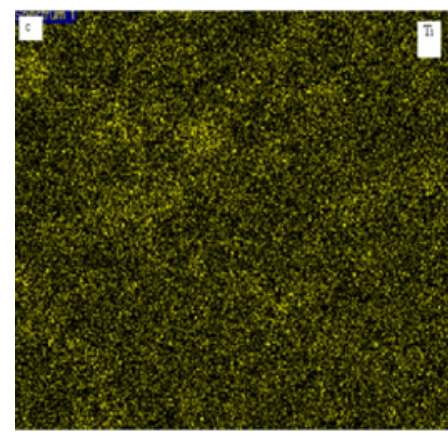

Ti

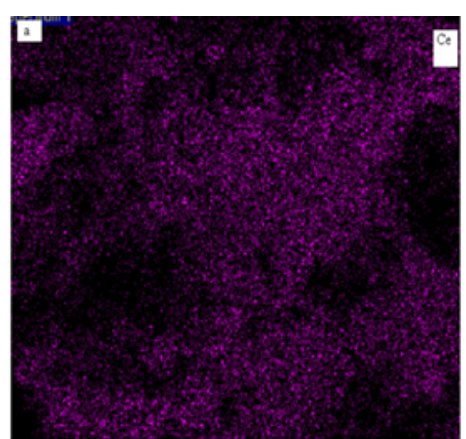

Ce

(a) $\mathrm{CZA}$

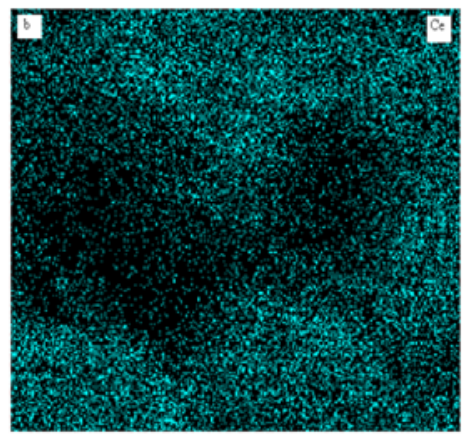

Ce

(b) $\mathrm{CZS}$

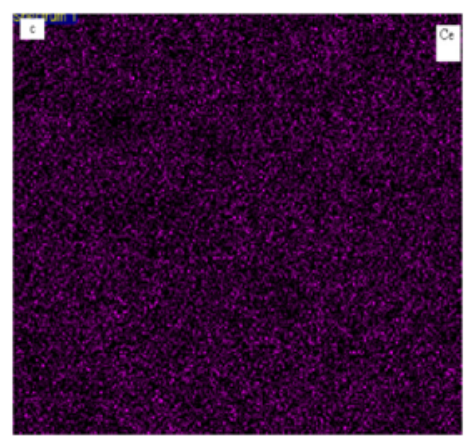

Ce

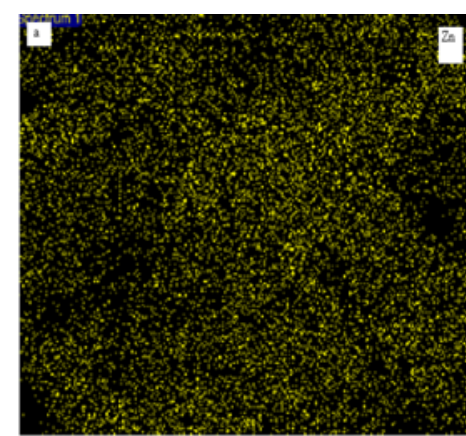

Zn

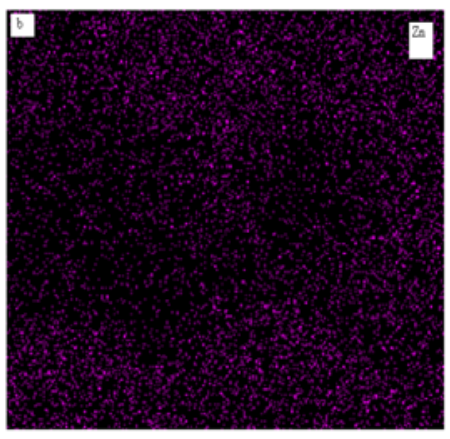

Zn

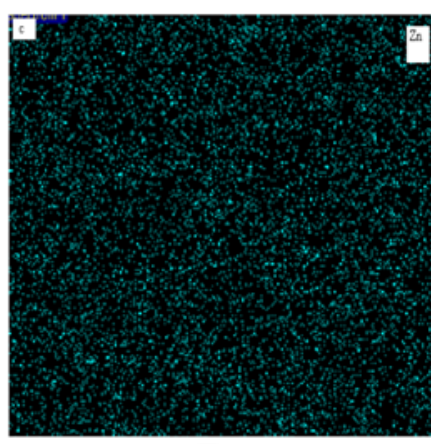

Zn

(c) $\mathrm{CZT}$

Fig. S1. EDX image mapping of (a) $\mathrm{Al}, \mathrm{Ce}, \mathrm{Zn}$ element in CZA, (b) Si, Ce, Zn element in CZS, and (c) Ti, Ce, Zn element in CZT. 


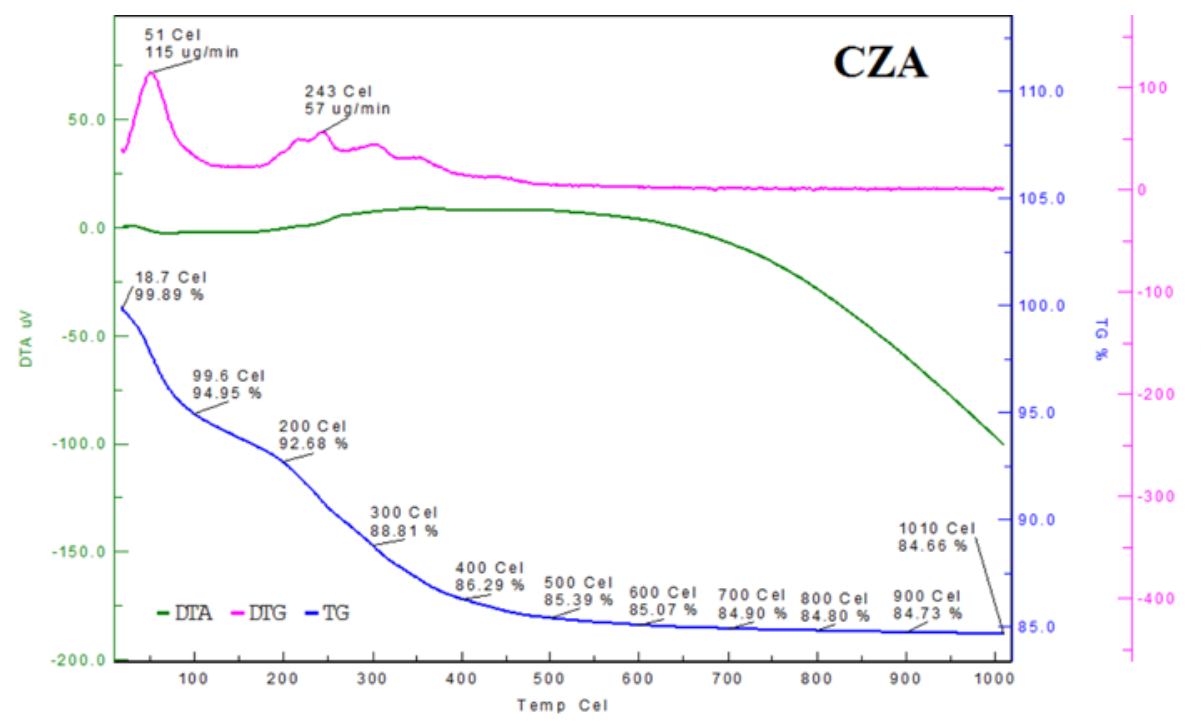

(a)

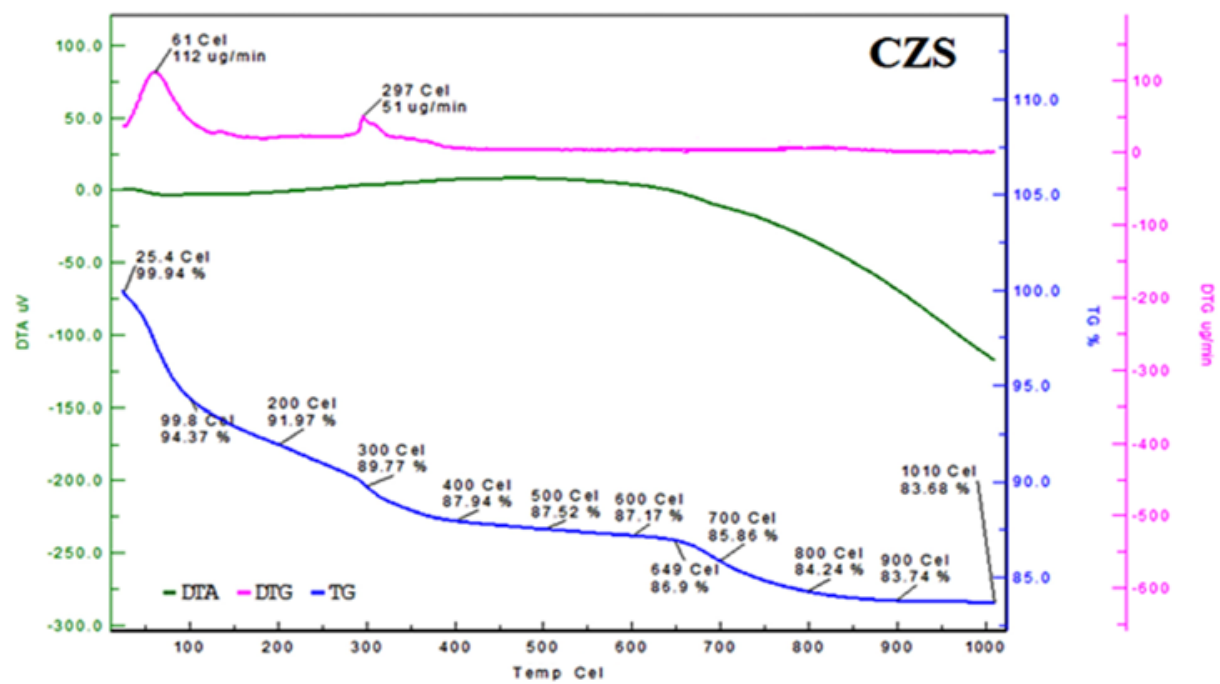

(b)

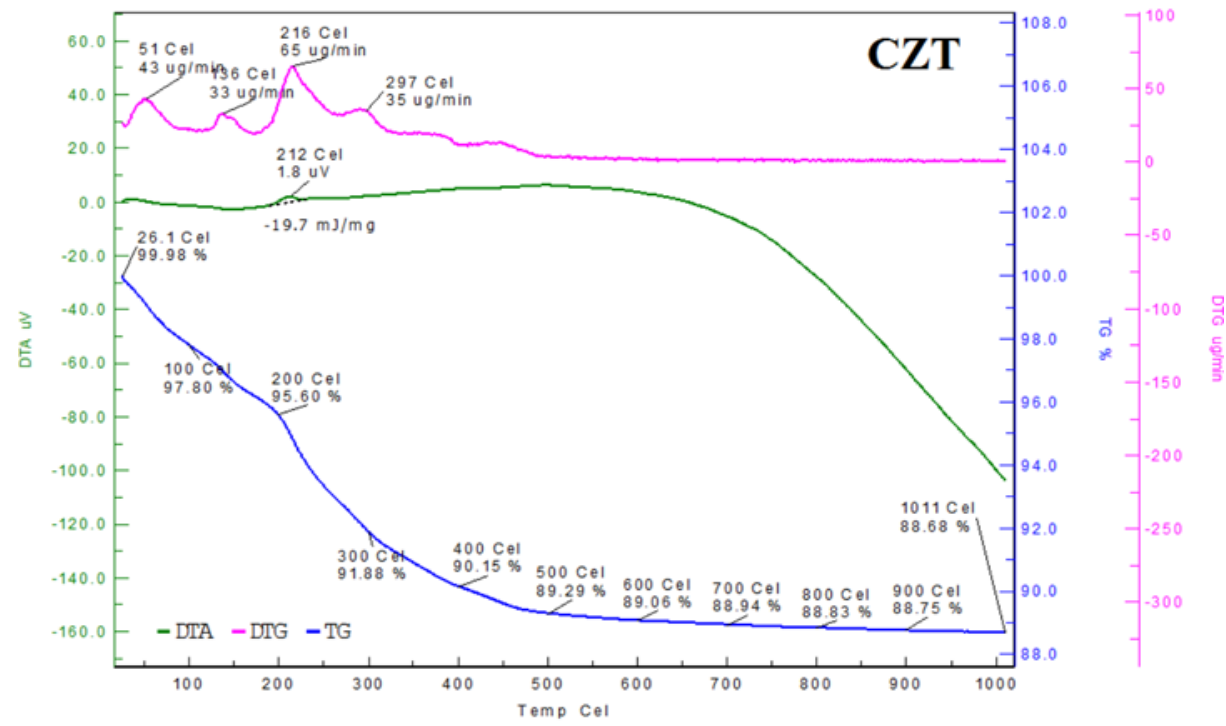

(c)

Fig. S2. TG/DTA/DTG of synthesized CZA, CZS and CZT catalysts. 